\title{
Når uddannelsessystemet skal rumme de mange og de særlige \\ - en midlertidig status på og diskussion af den særlige optagelsesprocedure i kvote 2 på Syddansk Universitet
}

\author{
Maria Cecilie Vonsild, cand.scient., AC-fuldmagtig, Enheden for Uddannelsesudvik- \\ ling, Syddansk Universitet. \\ Birgitta Wallstedt, cand.scient., leder af SDU Universitetspaedagogik, Syddansk Uni- \\ versitet.
}

\section{Reviewet artikel}

En midlertidig status for optagelsesproceduren $i$ kvote 2 på SDU viser, at studerende der er optaget $i$ kvote 2 har et signifikant lavere frafald sammenlignet med kvote 1-optagne. Det diskuteres hvordan optagelsesproceduren kan bidrage til en særlig talentudvalgelse samt matchning af ansøgerne i forhold til uddannelsens faglige profil.

\section{Baggrund}

Ministeriet for Forskning, Innovation og Videregående Uddannelser har i henhold til BEK 212 §13 stk. 2 udstedt nye bachelor- og kandidatadgangsbekendtgørelser ${ }^{1}$, . I en skrivelse til de enkelte universiteter d. 1. marts 2012, udsendte ministeriet en anmodning om indstilling af ønsker til kvotefordeling for kvote 1 og 2 for godkendte bacheloruddannelser. I skrivelsen stod bl.a.: "En kvotefastsættelse uden en bestemt fordeling som målsætning er et af flere elementer i Ministeriet for Forskning, Innovation og Videregående uddannelsers planer og overvejelser om større frihedsgrader og fornyelse af optagelsessystemet." Hermed åbnes en dør for at give universiteterne større frihed til fastlæggelse af kvotefordelinger, som hidtil har været fastsat i et 90:10-forhold for henholdsvis kvote 1 og 2.

Nedbringelse af frafald og øget indsats inden for fastholdelsesstrategier i uddannelsessystemet er et af de delmål, der nævnes i regeringsgrundlaget fra 2011 - Et Danmark der står sammen - i forhold til målsætningen om, at $60 \%$ af en ungdomsårgang skal have en videregående uddannelse og $25 \%$ skal have en lang videregående ud-

\footnotetext{
${ }^{1}$ www.retsinformation.dk/Forms/R0710.aspx?id=140232
} 
dannelse i $2020^{2}$. En af de strategier, der nævnes, er bl.a., at der skal tænkes i nye optagelsesformer, og med muligheden for at universiteterne kan gøre kvotefordelingen fri, skabes der nu også gode muligheder for forskning i og evaluering af forskellige optagelsesmetoder. I takt med at der skal oprettes flere studiepladser, er der et samfundsøkonomisk rationale i at forholde sig undersøgende til, hvordan optagelsessystemet skal indstille sig i forhold til kravet om, at uddannelsessystemet både skal kunne rumme flere studerende, samt at flere skal kunne gennemføre.

Supplerende til dette har uddannelsesministeren fremsat en række forslag til, hvordan uddannelsessystemet fremover bør satse målrettet på systematisering af talentudvikling med øje for identifikation og udvikling af særlige potentialer på individniveau og på tværs af uddannelser (Østergaard, 2012).

Når uddannelserne på denne måde både skal kunne rumme de mange og de særlige, stilles det fremtidige uddannelses- og optagelsessystem overfor nogle ganske omfattende udfordringer, hvorfor det traditionelle optagelsessystem, der i overvejende grad fokuserer på det adgangsgivende karaktergennemsnit, bør nytænkes. Formålet med denne artikel er derfor at sætte fokus på optagelsessystemets betydning for udvælgelse af de særligt egnede og forebyggelse af frafald samt diskutere, hvordan akademiske kvalifikationer kan måles. Dette gøres på baggrund af en midlertidig status på og diskussion af Syddansk Universitets særlige optagelsesprocedure i kvote 2.

\section{Midlertidig status for optagelsesproceduren i kvote 2}

Historik

Det sundhedsvidenskabelige Fakultet på Syddansk Universitet (SDU) har siden 2008 anvendt en særlig optagelsesprocedure til udvælgelse af kommende studerende i kvote 2. Den er særlig forstået på den måde, at SDU i 2008 efter en ansøgning fik tilladelse til at optage mellem 20 og 80 procent i kvote 2. Baggrunden for ansøgningen om det relativt store optag i kvote 2 var de meget positive erfaringer med lavere frafald blandt optagne i kvote 2 (eksperimentel kvote 2) fra en forudgående forsøgsperiode fra 2002-2007 (Wallstedt, 2004). Den er også særlig, fordi ansøgerne først går til en MCQ-test, der vurderer udvalgte kognitive kompetencer. MCQ-testen fungerer som præselektionstest, idet resultaterne herfra afgør, hvilke ansøgere der går videre til den næste optagelsesrunde. Denne del består af en række strukturerede optagelsessamtaler - det såkaldte Multiple Mini Interview (MMI) - hvor ansøgerne bedømmes på forskellige udvalgte kompetencer som etisk dømmekraft, samarbejdsevner samt indsigt i og forståelse for de specifikke uddannelser de søger ind på.

${ }^{2}$ www.stm.dk/_p_7811.html 
Beskrivelse af optagelsesprocedurens tests siden 2008

I hovedtræk består den nuværende optagelsesprocedure (siden 2008) altså af to testformater:

1. MCQ-testen. MCQ-testen er udformet i samarbejde mellem the Australian Council for Educational Research (ACER) og Cambridge Assessment under betegnelsen uniTEST. Testen er valideret på australske universitetsstuderende, hvor den anvendes som supplement til det adgangsgivende karaktergennemsnit (Coates et al., 2010). ACER er en privat organisation med over 80 års erfaring i udvikling af adgangsprøver, særligt med fokus på supplerende adgangstests til universiteter i bl.a. Australien og Storbritannien ${ }^{3}$. Cambridge Assessment er en "non profit" organisation under Cambridge University ${ }^{4}$. MCQ-testen oversættes fra engelsk til dansk og består af 90 spørgsmål. Den er designet til at måle kognitive kompetencer inden for 3 udvalgte domæner: Kritisk, kvantitativt og sprogligt ræsonnement. Hvert domæne vægtes ligeligt i den endelige resultatopgørelse. Testen har fungeret med høj grad af reliabilitet (intern konsistens) med en Cronbachs Alfa-koefficient mellem 0,86 og 0,88 i de år, den har været anvendt på SDU (2008 - 2012).

2. MMI-testen. MMI-testen er udviklet på Michael DeGroote School of Medicin på McMaster University i Canada i 2004 (Eva et al., 2004) og er sidenhen blevet anvendt som optagelsesprocedure på en række universiteter (fx Brownell et al., 2007; Harris \& Owen, 2007; Hecker et al., 2009). På hver uddannelse består selve indholdsvalideringen af MMI af udarbejdelse af et såkaldt blueprint, hvor der genereres et matrix for de specifikke kriterier ansøgerne skal bedømmes på ved de enkelte samtalestationer. Blueprintet er udarbejdet af et fagligt ekspertpanel fra de respektive uddannelser med det primære formål at sikre det optimale match mellem den studerende og uddannelsen. Det andet formål er, at selve optagelsesproceduren udfordrer den enkelte ansøgers overvejelser i forhold til at kunne begrunde sit studievalg. Hypotesen er, at dette vil sikre optagelse af motiverede og målrettede studerende, der udviser drivkraft og vedholdenhed i forhold til at fuldføre uddannelsen.

Et MMI-forløb består typisk af 6 - 8 stationer (afhængig af uddannelse), hvor hver ansøger starter samtidig med de andre men ved hver deres station. Interviewet varer 8 minutter, og når interviewet er slut ved én station roterer ansøgerne videre til den næste station. Der er én interviewer ved hver station. MMI testen fungerer med høj grad af reliabilitet og har også vist sig prædikativ i forhold til kliniske færdigheder og præstation ved OSCE-eksamen (Eva et al., 2009; LeMay et al., 2007; Reiter et al., 2007; Roberts et al., 2009). Styrken ved anvendelse af denne type af strukturerede

\footnotetext{
${ }^{3}$ www.acer.edu.au

${ }^{4}$ www.cambridgeassessment.org.uk/ca/
} 
optagelsessamtaler er undgåelse af kontekstafhængighed, fordi bedømmelsen af én færdighed ved én MMI-station ikke nødvendigvis bliver overført til den næste MMIstation.

Eksempler på MCQ-spørgsmål samt beskrivelse af de bedømmelseskriterier, der anvendes til MMI på de forskellige sundhedsvidenskabelige uddannelser, kan hentes på SDU's hjemmeside ${ }^{5}$ :

Foreløbig evaluering af optagelsesproceduren i kvote 1 og 2 på SDU (2008-10): Frafald, beståelse og gennemforsel

Evalueringen af kvote 2-proceduren siden 2008 er baseret på deskriptive, statistiske analyser for frafald, beståelsesprocent og gennemførsel. Opgørelserne omfatter alle optagne studerende på uddannelserne Medicin, Psykologi, Klinisk Biomekanik og Idræt \& Sundhed for årgang 2008 - 2010, både i kvote 1 og 2 (Studieservice, SDU, 2012). Bemærk dog at Psykologi først optræder i opgørelserne fra år 2010, hvor uddannelsen startede på SDU.

Optagne, som har afbrudt uddannelsen inden for den første måned efter studiestart, indgår ikke i opgørelsen af hensyn til overensstemmelse med Danske Universiteters nøgletal G. Dette er den officielle indberetningsmetode, der anvendes af alle danske universiteter.

Tabel 1. Oversigt der viser fordelingen af optagne studerende fordelt på årgang, uddannelse og kvote.

\begin{tabular}{|l|l|r|r|}
\hline Årgang & Uddannelse & Kvote 1 * & Kvote 2 * \\
\hline $\mathbf{2 0 0 8}$ & Medicin & 149 & 117 \\
& Klinisk Biomekanik & 8 & 23 \\
& Idræt og Sundhed & 30 & 46 \\
\hline $\mathbf{2 0 0 9}$ & Medicin & 115 & 194 \\
& Klinisk Biomekanik & 27 & 37 \\
& Idræt og Sundhed & 33 & 62 \\
\hline $\mathbf{2 0 1 0}$ & Medicin & 130 & 165 \\
& Klinisk Biomekanik & 22 & 41 \\
& Idræt og Sundhed & 37 & 78 \\
& Psykologi & 83 & 25 \\
\hline
\end{tabular}

I henhold til Den koordinerede Tilmelding (KOT) er definitionen af kvote 1 og 2, at ansøgere i kvote 1 optages på baggrund af eksamenskvotienten fra den adgangsgivende eksamen, mens optagelsen i kvote 2 er for de ansøgere, der ikke har højt nok gennemsnit til at blive optaget i kvote 1 eller har brug for at blive vurderet på andre

${ }^{5}$ www.sdu.dk/Uddannelse/Optagelse/Bacheloruddannelser/Kvote_2/Optagelsesproever_MCQ_MMI 
kvalifikationer ud over eksamensgennemsnittet. I denne sammenhæng er definitionen af kvote 1 dog udvidet i forhold til at kunne foretage en sammenligning mellem den gruppe, der er blevet udvalgt efter optagelsesproceduren, med den gruppe der er blevet optaget i kvote 1, og som aldrig ville være blevet optaget efter kvote 2-prøverne. Eksempelvis kan en kvote 2-ansøger, der har bestået optagelsesprøverne, blive optaget i kvote 1 (teknisk optaget), hvis ansøgerens adgangskvotient er $>$ eller = årets grænsekvotient for den valgte uddannelse, men den pågældende ansøger vil indgå $i$ kvote 2-gruppen, fordi han/hun er udvalgt efter prøverne. Endvidere kan en kvote 2-ansøger, der ikke bestod optagelsesprøverne, godt blive optaget i kvote 1, idet alle kvote 2-ansøgere automatisk bliver vurderet i kvote 1 og bliver optaget i denne ordning, hvis deres adgangskvotient er > eller = årets grænsekvotient. Denne ansøger vil indgå i kvote 1-gruppen.

Definitionen af kvote lyder derfor:

Kvote 1

- Optaget på baggrund af gennemsnit, har ikke deltaget i kvote 2-prøverne.

- Optaget på gennemsnit, afvist efter kvote 2-prøverne.

Kvote 2

- Udvalgt og optaget på baggrund af kvote 2-prøverne

- Udvalgt efter kvote 2-prøverne, men teknisk optaget i kvote 1

De foreløbige resultater samlet for de fire uddannelser på Det sundhedsvidenskabelige Fakultet, der har anvendt den særlige optagelsesprocedure i kvote 2, præsenteres i følgende tre tabeller:

Tabel 2. Status på frafald efter 1. studieår fordelt på kvote (2008-2010): Medicin, Klinisk Biomekanik, Idræt og Sundhed, Psykologi.

\begin{tabular}{|l|l|l|l|l|l|l|}
\hline \multirow{2}{*}{} & \multicolumn{2}{|l|}{ Antal } & Procent \\
\cline { 2 - 7 } & Afbrudt & Aktiv & I alt & Afbrudt & Aktiv & I alt \\
\hline Kvote 1 & 43 & 591 & 634 & 6.8 & 93.2 & 100 \\
\hline Kvote 2 & 29 & 759 & 788 & 3.7 & 96.3 & 100 \\
\hline I alt & 72 & 1.350 & 1.422 & 5.1 & 94.9 & 100 \\
\hline
\end{tabular}

Likelihood ratio( $p$-værdi $)=0,0082$. 
Tabel 3. Status på førsteårsprøve efter 2. studieår fordelt på kvote (2008-2009): Medicin, Klinisk Biomekanik, Idræt og Sundhed.

\begin{tabular}{|l|l|l|l|l|l|l|}
\hline & \multicolumn{2}{|l|}{ Antal } & \multicolumn{2}{l|}{ Procent } \\
\cline { 2 - 7 } & Bestået & Ikke-bestået & I alt & Bestået & Ikke-bestået & I alt \\
\hline Kvote 1 & 321 & 41 & 362 & 88.7 & 11.3 & 100 \\
\hline Kvote 2 & 453 & 26 & 479 & 94.6 & 5.4 & 100 \\
\hline I alt & 774 & 67 & 841 & 92.0 & 8.0 & 100 \\
\hline
\end{tabular}

Likelihood ratio $(p$-værdi) $=0.0019$

Tabel 4. Status på gennemførsel på normeret tid efter 3. studieår fordelt på kvote (2008): Medicin, Klinisk Biomekanik, Idræt og Sundhed.

\begin{tabular}{|l|l|l|l|l|l|l|}
\hline & \multicolumn{2}{|l|}{ Antal } & Procent & \multicolumn{2}{l|}{} \\
\cline { 2 - 7 } & Afsluttet & Ikke-afsluttet & I alt & Afsluttet & Ikke-afsluttet & I alt \\
\hline Kvote 1 & 112 & 75 & 187 & 59.9 & 40.1 & 100 \\
\hline Kvote 2 & 101 & 85 & 186 & 54.3 & 45.7 & 100 \\
\hline I alt & 213 & 160 & 373 & 57.1 & 42.9 & 100 \\
\hline
\end{tabular}

Likelihood ratio ( $p$-værdi) $=0.2751$

Resultaterne for frafald viser, at der er et statistisk signifikant mindre frafald i kvote 2 (tabel 2), sammenlignet med optagne i kvote 1, et år efter studiestart.

I tabel 3 kan det aflæses, at der er en statistisk signifikant større andel af optagne i kvote 2, der består førsteårsprøven indenfor to år efter studiestart (på uddannelserne Medicin, Klinisk Biomekanik og Idræt og Sundhed).

I tabel 4 opgøres gennemførsel på normeret tid tre år efter studiestart, hvorfor kun årgang 2008 indgår. Her kan der ikke aflæses en statistisk signifikant forskel på, hvor hurtigt der gennemføres i forhold til, om man er optaget i den ene eller den anden kvote.

\section{Diskussion af den særlige optagelsesprocedure i kvote 2}

Udvælgelsen af de særlige

I Morten Østergaards debatoplæg Plads til talenterne (Østergaard, 2012) beskrives de særlige som de studerende, der har et åbenlyst potentiale/talent for at kunne (videre)udvikle særlige evner indenfor et givent fagområde. I debatoplægget fremsættes en række forslag til, hvordan uddannelsessystemet kan udvide rammerne for, hvordan særlige talenter kan opnå optimale vækstbetingelser som led i en talentudviklingsog fastholdelsesstrategi.

Den særlige optagelsesprocedure i kvote 2 kan i denne sammenhæng bidrage yderligere til disse strategier i forhold til talentudvælgelse, idet proceduren skaber mulighed for både at selektere blandt ansøgerne i forhold til at sikre det optimale match mellem den enkelte ansøgers kompetencer og uddannelsen, samt opdage talenterne under 
optagelsesprøverne. Optagelse af studerende på baggrund af en eksamenskvotient fra en alment dannende gymnasial uddannelse kan ikke på samme måde sikre, at en sådan matchning mellem den studerende og uddannelsen finder sted. Endvidere skabes der mulighed for, at en given uddannelse finder et særligt talent på et langt tidligere tidspunkt, end det måske ellers ville have været tilfældet i uddannelsesforløbet (hvis talentet overhovedet ville blive opdaget). Dette kan igen bidrage til den videre udvikling af talentet med eksempelvis individuelle studieplaner, der kan understøtte den studerendes motivation for og lyst til at blive på uddannelsen.

Når uddannelserne i fremtiden også skal kunne rumme de mange, er det yderst relevant, at optagelsessystemet målrettes i forhold til at rekruttere studerende, der ikke blot har potentiale for et godt akademisk forløb men bestemt også for at kunne gennemføre uddannelsen. Nedbringelse af frafald er derfor et væsentligt undersøgelsesparameter i forhold til videre optagelsesforskning, og det følgende afsnit vil diskutere SDU's evaluering af optagelsesprocedurens effekt på frafald.

\section{Forebyggelse af frafald}

De foreløbige opgørelser af kvote 2-procedurens betydning for frafald viser, at de studerende, der var optaget i kvote 2 , havde et statistisk signifikant lavere frafald et år efter studiestart sammenlignet med de studerende, der var optaget i kvote 1 $(\mathrm{p}=0,008)$. Omend resultaterne skal tages med det forbehold, at de er deskriptive og præliminære, er de i tråd med de forskningsresultater, der tidligere er udgået fra Syddansk Universitet (O'Neill, L. et al., 2011). Her viste det sig, at den relative risiko for at falde fra inden for to år efter studiestart var 1,8 gange større, hvis man var optaget i kvote 1 sammenlignet den gruppe af studerende, der var optaget i kvote 2 ud fra en kohorte på 1544 medicinstuderende (den eksperimentelle kvote 2, årgang 2002-2007).

Ud over SDU's tidligere resultater findes der ganske få veldokumenterede studier af effekten af særlige optagelsesparametre på frafald. Et enkelt dansk studie om fastholdelse på Jordemoderuddannelsen viser, at hele $75 \%$ af de studerende, der faldt fra studiet i årerne 2004-10, var studerende, der var blevet optaget i kvote 1 (Marcussen \& Rydahl, 2012). Derudover har et studie fra Østrig (Reibnegger et al., 2011) og et enkelt hollandsk studie (Urlings-Strop et al., 2011) fundet en positiv sammenhæng mellem udvælgelsestests og lavere frafald. Men det er fortsat et forskningsområde, der uomtvisteligt kræver flere kohorteundersøgelser kontrolleret for multivariable faktorer, der kan tænkes at påvirke frafald. Med disse forbehold i tankerne, tyder den foreløbige evaluering dog på, at tendensen til lavere frafald blandt kvote 2optagne fortsætter.

Men hvad skyldes denne tendens? I et studie fra Utrecht Universitet i Holland undersøgte man graden af motivation for at gennemføre uddannelsen blandt 418 første- 
og andetårs medicinstuderende. Disse studerende var blevet optaget på uddannelsen via tre forskellige optagelsesmetoder: 1) Direkte adgang (højeste karakterer); 2) særligt udvalgt efter optagelsessamtaler; 3) tilfældigt udvalgt via en vægtet lodtrækning, hvilket vil sige, at jo højere karakterer ansøgerne har, jo flere lodsedler får de. Her fandt man, at de særligt udvalgte studerende var signifikant mere motiverede end de hhv. tilfældigt udvalgte og de studerende, der var optaget på baggrund af højeste karakterer (Hulsman et al., 2007). Dette kunne altså tyde på, at optagelsesmetode gør en forskel for graden af motivation. Den norske psykolog Guru Øiestad (2006) beskriver, hvordan vi som mennesker har et helt basalt behov for at føle os kompetente som motor for motivation. For at opnå følelsen af tro på egne evner er vi afhængige af konstruktiv feedback fra mennesker (forældre, arbejdsgivere, kollegaer, venner osv.), som vi selv synes er kompetente, har en relation til og har tillid til. I en talentrapport udarbejdet til Undervisningsministeriet beskrives bl.a., at det virker anerkendende at blive udvalgt, opfordret og peget ud, og det stimulerer til øget motivation og vilje (Arbejdsgruppen til talentudvikling i uddannelsessystemet, 2011)En nærliggende hypotese kunne derfor være, at ansøgernes møde med interviewerne til optagelsessamtalerne, som alle er kvalificerede repræsentanter fra uddannelsen (undervisere, forskere, ph.d.-studerende osv.), skaber en sådan motivationseffekt.

Men tro på egne evner er ikke en langtidsholdbar katalysator for motivation, hvis den ikke samtidig er determineret af en indre grad af autonomi (Deci \& Ryan, 2002). Med andre ord, hvis drivkraften for ens handlinger ikke føles meningsgivende på et dybere plan, forgår den indre motivation med tiden. Vel er det vigtigt, at uddannelserne målretter tiltag, der på systematisk vis identificerer og skaber udvikling til vækst hos de åbenlyst talentfulde studerende, der gerne vil og kan yde mere end det, der kræves af det ordinære forløb, for uden motivation og træning forgår talentet. Men mange af de talentudviklingsforslag der rejses af Morten Østergaard forudsætter, at der også er en iboende vilje til stede. I denne kontekst har optagelsessamtalerne en vigtig funktion i forhold til at sikre, at de kandidater, der vurderes, også besidder en indre drivkraft, der holder ved trods akademiske barrierer. Ansøgernes personlige overvejelser og viden om uddannelsens relaterede emner og temaer er et spejl af deres indre og ydre motiver for at vælge det pågældende studie og må nødvendigvis være udkrystalliseret $\mathrm{i}$ bevidstheden hos den enkelte for, at bedømmeren på den anden side også kan blive overbevist om den pågældende ansøgers potentiale og drivkraft til at kunne gennemføre uddannelsen med dens mange krav og udfordringer.

\section{Akademiske kvalifikationer}

Høje karakterer i gymnasiet opfattes generelt som udtryk for akademiske kvalifikationer, og både dansk og udenlandsk forskning viser, at det gymnasiale karaktergennemsnit er den bedste prædiktor for opnåede karakterer under studiet (Christensen 
\& Juul, 1999; Ferguson et al., 2002). Dette bekræftes også i vores nye undersøgelse (baseret på kohorten af medicinstuderende fra 2002-2007) af de adgangsgivende eksamenskarakterers betydning for, hvor høje karakterer der opnås under medicinstudiet. Men i undersøgelsen kom vi også frem til det resultat, at selvom der var en gennemsnitlig karakterforskel på 2,4 på adgangstidspunktet mellem de to kvoter, så skrumpede forskellen ind til 0,58 i bachelorgennemsnittet ( $\mathrm{O}^{\prime}$ Neill et al., 2012).

Andre relevante mål for akademiske kvalifikationer er beståelsesfrekvens og gennemførselshastighed. I evalueringen af optagelsesproceduren viste det sig, at der var statistisk signifikant forskel på beståelsesfrekvensen afhængig af hvilken kvote de studerende var optaget i: 94,7\% af de studerende der var blevet optaget i kvote 2 bestod førsteårsprøven indenfor 2 år efter studiestart, mod 88,7\% af de studerende der var blevet optaget i kvote 1 (tabel 3). Endvidere viser tabel 4, at der ikke kunne påvises en statistisk signifikant forskel på, om man var optaget i kvote 1 eller 2 for gennemførsel på normeret tid efter 3 år. Denne tendens er, ligesom opgørelserne for frafald, næsten i tråd med SDU's forskningsresultater baseret på kohorten fra $2002-07$. Her fandt man, at der hverken var signifikant forskel på kvoternes beståelsesfrekvens eller progressionshastighed (O’Neill, 2012).

På baggrund af SDU's forskning på den tidligere kohorte (2002-07) er der ikke noget der tyder på, at optagelse i kvote 1 eller 2 udgør en væsentlig forskel på, hvor godt de studerende klarerede sig akademisk, hvis akademiske kvalifikationer måles ud fra karakterer. Måles akademiske kvalifikationer ud fra gennemførsel på normeret tid, eller beståelse af prøverne indenfor tidsrammen udgør kvote heller ingen forskel.

I det hele taget er en udvidelse af tankegangen omkring hvad, der karakteriserer akademiske kvalifikationer, og hvordan de kan måles, kærkommen: Eksempelvis rummer de sundhedsvidenskabelige uddannelser mange facetter og specialer, hvorfor det er en fordel, at forskning i optagelse fremover også forholder sig undersøgende til andre mål for akademiske kvaliteter. Det kunne eksempelvis være engagement i studiesociale aktiviteter, deltagelse i undervisningen, samarbejdsevner eller deltagelse i læsegrupper.

\section{Konklusion}

Med regeringens ambitiøse målsætning om, at $60 \%$ af en ungdomsårgang skal gennemføre en videregående uddannelse og $25 \%$ skal have en lang videregående uddannelse i 2020, er der et åbenlyst rationale for fornyelse af optagelsessystemet i forhold til fastholdelsesstrategier og nedbringelse af frafald. Med baggrund i SDU's midlertidige status på og diskussion af den særlige optagelsesprocedure i kvote 2, har vi i den sammenhæng ønsket at sætte fokus på følgende områder: 


\section{Talentudvælgelse:}

Udvælgelse af de særlige kan være med til at sikre det rette match mellem den studerende og uddannelsen samt, at talenter opdages på et tidligt tidspunkt. Udover selve matchningen kan dette give uddannelserne gode muligheder for at skærpe indsatsen i forhold til talentudvikling på individniveau således, at de studerende forbliver motiverede og fastholdes på uddannelsen.

\section{Nedbringelse af frafald}

Evalueringen af optagelsesprocedurens effekt på frafald viser, at der er statistisk signifikant lavere frafald et år efter studiestart blandt de studerende, der var blevet udvalgt i kvote 2 . Resultaterne er i tråd med de dokumenterede forskningsresultater fra den tidligere 2002-7 kohorte (eksperimentelle kvote 2), der viste, at kvote 2 udgør en selvstændig beskyttende effekt på frafald.

\section{Akademiske kvalifikationer}

Adgangsgivende karakterer er ikke et isoleret mål for, hvor godt man klarer sig under uddannelsen. SDU's forskning (eksperimentel kvote 2) viser, at der ikke er nogen væsentlig forskel mellem de to kvoter på beståelsesfrekvens eller gennemførselshastighed.

Fremtidige undersøgelser bør sætte fokus på de potentielle sammenhænge, der er mellem optagelsesmetoder, motivation og fastholdelse samt undersøge flere relevante variable, der kan tænkes at påvirke eksempelvis frafald, beståelse og gennemførsel. Endvidere bør akademiske kvalifikationer også undersøges ud fra andre mål end karakterer, for eksempel studieadfærdsmønstre.

Maria Cecilie Vonsild er AC-fuldmægtig ved Enheden for Uddannelsesudvikling for Det Sundhedsvidenskabelige Fakultetssekretariat på Syddansk Universitet, hvor hun bl.a. er projektleder for kvote 2optagelsesprøverne på idrætsstudiet, kiropraktorstudiet, psykologistudiet og medicinstudiet.

Birgitta Wallstedt er leder af SDU Universitetspæedagogik, Syddansk Universitet. Hun har vxret primus motor for implementering af kvote 2-optagelsesprøverne på Sundhedsvidenskab og har publiceret på dansk og engelsk om optagelse og frafald.

\section{Referencer}

Arbejdsgruppen til talentudvikling i uddannelsessystemet (2011). Viden om talent og talentudvikling. http://www.uvm.dk/Service/ /media/UVM/Filer/Udd/Folke/PDF11/110414 Tal entrapport hele.ashx (tilgået 09.08.12)

Brownell, K., Lockyer, J., Collin, T., \& Lemay, J. F. (2007). Introduction to the multiple mini interview into the admissions process at the University of Calgary: Acceptability and feasibility. I: Medical Teacher 29, s. 394-396.

Christensen, J., \& Juul, S. (1999). Adgangsgivende eksamens indflydelse på lægeud- 
dannelsen. I: Ugeskrift for Læger 161(3), s. 257-262.

http://www.ugeskriftet.dk/lf/UFL/uf199 00/1999 2000/ufl9903/v p/257.htm

(tilgået 24.01.13)

Coates, H., Edwards, D., Friedman, T. (2010). Student aptitude test for tertiary admission (SATTA) pilot program. Evaluation report for the Department of Education, Employment and Workplace Relations (DEEWR). Australian Counsil for Educational Research.

Deci, E. L. \& Ryan, R. M. (2002). An overview of self-determination theory: An organismic-dialectical perspective. I: Deci, E. L. \& Ryan R. M. (Red.), Handbook of Self-Determination Research. Rochester: The University of Rochester Press. USA, s. 3-33.

Eva, K. W., Rosenfeld, J., Reiter, I. H., \& Norman, R. G. (2004). An admissions OSCE: The multiple mini interview". I: Medical Education 38, s. 314-326.

Eva K. W., Reiter, H. J., Trinh, K., Wasi, P., Rosenfeld, J., Norman, G. R. (2009). Predictive validity of the multiple mini interview for selecting medical trainees. I: Medical Education. 43(8), s. 767-775.

Ferguson, E., James, D., \& Madeley, L. (2002). Factors associated with success in medical school: Systematic review of the literature. I: British Medical Journal 324(7343), s. 952-957.

http://www.bmj.com/highwire/filestream/349199/field highwire article pdf/0. pdf (tilgået 24.01.13).

Harris, S. \& Owen, C. (2007). Discerning quality: Using the multiple mini interview in student selection for the Australian National University Medical School. I: Medical Education 41(3), s. 234-241.

Hecker, K., Donnon, T., Fuentealba C., Hall, D., Illanes, O., Morck, D. W., Muelling, C. (2009). Assessment of applicants to the veterinary curriculum using a multiple mini-interview method. I: Journal of Veterinary Medical Education 36(2), s. 166-173.

Hulsman, R. L. van der Ende, J. S., Oort, F. J., Michels, R. P., Casteelen G., \& Griffioen, F. M. (2007). Effectiveness of selection in medical school admissions: Evaluation of the outcomes among freshmen. I: Medical Education 41(4), s.369377.

LeMay, J. F., Lockyer, J. M., Collin, V. T., Brownell, A. K. (2007). Assessment of noncognitive traits through the admissions multiple mini-interview. I: Medical Education 41(6), s. 573-579.

Marcussen, S. B. \& Rydahl, E. (2012). Fastholdelse på Jordemoderuddannelsen, 2004-2010. https://www.ucviden.dk/portalmetropol/files/11835564/Fastholdelse_endelig_rapport_2.pdf (tilgået 24.01.13).

O’Neill, L.D., Hartvigsen, J., Wallstedt, B., Korsholm, L., \& Eika, B. (2011). Medical school dropout - testing at admission versus selection by highest grades as predictors. I: Medical Education 45(11), s. 1111-1120. 
O’Neill, L.D., Vonsild, M.C., Wallstedt, B. (2013). Kvote 2 og akademiske præstationer: Hvor stor en betydning har det adgangsgivende gennemsnit? I: Dansk Universitetspædagogisk Tidsskrift 8(14).

Reibnegger, G., Caluba, H. C., Ithaler, D., Manhal, S., Neges, H. M., \& Smolle, J. (2011). Dropout rates in medical students at one school before and after the installation of admission tests in Austria. I: Academic Medicine 86(8), s. 1040-1048.

Reiter, H. I.,_Eva, K. W., Rosenfeld, J., Norman, G. R. (2007). Multiple mini interview predict clerkship and licensing examination performance. I: Medical Education 41(4), s. 378-384.

Studieservice (2012): Dokumentation til evaluering af kvote 2 proces: Frafald, Førsteårsprøve, Gennemførsel. Intern rapport udarbejdet af Analyse og kvalitetsudvikling, Syddansk Universitet.

Urlings-Strop, L. C. Stijnen, T., Themmen, A. P. N., \& Splinter, T. A. W. (2009). Selection of medical students: A controlled experiment. I: Medical Education 43(2), s. 175-183.

Roberts, C., Zoanetti, N., Rothnie, J. (2009). Validating a multiple mini-interview question bank assessing entry-level reasoning skills in candidates for graduateentry medicine and dentistry programmes. I: Medical Education 43(4), s. 350-359.

Wallstedt, B. (2004). Optagelse af studerende til lægeuddannelsen. I: Ugeskrift for læger 166(21), s. 1980-1983.

Øiestad, G. (2006). Feedback. København: Dansk Psykologisk Forlag.

Østergaard, M. (2012). Debatoplæg fra uddannelsesminister Morten Østergaard: Plads til talenterne http://fivu.dk/aktuelt/pressemeddelelser/2012/filer/15-06debatoplaeg-plads-til-talenterne.pdf (tilgået 24.01.13) 